\title{
Straw mulching and nitrogen application altered ammonia oxidizers communities and improved soil quality in the alkaline purple soil of southwest China
}

Songhe Chen ${ }^{1 \dagger}$, Rencai Gao ${ }^{1 \dagger}$, Xiaoling Xiang ${ }^{1 \dagger}$, Hongkun Yang ${ }^{1}$, Hongliang Ma ${ }^{1}$, Ting Zheng ${ }^{1}$, Yun Xiao ${ }^{1}$, Xue Zhang ${ }^{1}$, Han Li ${ }^{1}$, Gaoqiong Fan ${ }^{1 *}$ and Yang Yu ${ }^{2^{*}}$

\begin{abstract}
Microbe-mediated ammonia oxidation is a key process in soil nitrogen cycle. However, the effect of maize straw mulching on the ammonia oxidizers in the alkaline purple soil remains largely unknown. A three-year positioning experiment was designed as follows: straw mulching measures as the main-plot treatment and three kinds of nitrogen application as the sub-plot treatment. We found the contents of soil organic carbon (SOC), total nitrogen (TN), available potassium (AK), available nitrogen (AN), available phosphorus (AP), and $\mathrm{NH}_{4}{ }^{+}-\mathrm{N}$ were increased after straw mulching and nitrogen application in alkaline purple soil, so did the amoA genes abundance of ammonia-oxidizing archaeal (AOA) and bacterial (AOB). Terminal restriction fragment length polymorphism (T-RFLP) analysis revealed that Thaumarchaeote (448-bp T-RF) was dominated the AOA communities, whereas Nitrosospira sp (111-bp T-RF) dominated the AOB communities. The community compositions of both $\mathrm{AOA}$ and $\mathrm{AOB}$ were altered by straw mulching and nitrogen application in alkaline purple soil, however, the AOB communities was more responsive than AOA communities to the straw mulching and nitrogen application. Further analysis indicated that SOC and AP were the main factors affecting the abundance and community compositions of $A O A$ and $A O B$ in alkaline purple soil. The present study reported that straw mulching and nitrogen strategies differently shape the soil ammonia oxidizers community structure and abundance, which should be considered when evaluating agricultural management strategies regarding their sustainability and soil quality.
\end{abstract}

Keywords: Alkaline purple soil, Straw mulching, Nitrogen, Ammonia-oxidizing archaea, Ammonia-oxidizing bacteria, AmoA genes

\footnotetext{
*Correspondence: fangao20056@126.com; yangyu0221@139.com

tSonghe Chen, Rencai Gao and Xiaoling Xiang contributed equally to this work

${ }^{1}$ Key Laboratory of Crop Eco-Physiology \& Farming System in Southwest China, Ministry of Agriculture, Sichuan Agricultural University, Chengdu 611130, Sichuan Province, China

2 Soil and Fertilizer Institute, Sichuan Academy of Agricultural Sciences, Chengdu 610066, Sichuan Province, China
}

\section{Introduction}

Nitrification is an important aspect of the soil nitrogen cycle, which helps crops to absorb soil nitrogen and regulate soil nitrogen loss (Liu et al. 2019). Ammonia oxidation is the rate-limiting step of nitrification and plays an important role in the nitrogen cycle; it is driven by ammonia oxidation archaea (AOA) and bacteria (AOB). Ammonia oxidizers contain the $a m o A$ gene that encodes the ammonia monooxygenase (AMO), which regulates the first step in ammonia oxidation and is usually used as 
the biomarker for the analysis of ammonia-oxidizer communities (Wang et al. 2019).

$\mathrm{AOA}$ and $\mathrm{AOB}$ have been found to exist widely in most agricultural soils and are influenced by soil environmental factors and tillage management practices (Wessén et al. 2010; Li et al. 2015). For example, AOA are favoured in low $\mathrm{pH}$ and ammonia-poor soil environments (Zhang et al. 2012), while AOB dominate nitrification in high nitrogen, and neutral or alkaline soils (Di et al. 2009). Studies have indicated that the abundance of AOA is higher than that of $\mathrm{AOB}$ both in alkaline and acidic purple soils (Zhou et al. 2016). However, the response of AOA and AOB community compositions and abundances for agricultural cultivation management were not consistent (Liu et al. 2015). Previous studies have shown that the application of chemical fertilization increases AOB abundance and changes its community composition, but had little influence on AOA in calcareous fluvoaquic soil (Ai et al. 2013). Moreover, some researchers have demonstrated that organic input has no significant effect on the composition of AOA community in sandy loam (Zhang et al. 2019), while Zhalnina et al. (2012) found that the addition of organic matter increased AOA abundance and had major influence on the AOA communities in the acidic red soil. In addition, the implications of straw returning and chemical $\mathrm{N}$ fertilization for soil microbial community have been extensively studied. $\mathrm{Hu}$ et al. (2019) showed that straw returning, $\mathrm{N}$ fertilization, and their interactions significantly increased the abundance of AOA and AOB in paddy soil, and AOA was more abundant than AOB. Similarly, further research revealed that fertilizer combined with straw could increase $\mathrm{AOB}$ number, and $\mathrm{AOA}$ was more abundant than AOB in clay loam (Wessén et al. 2010). However, some studies indicated that adding straw did not alter the abundance of AOA and AOB significantly in sandy soil (Wu et al. 2017). Therefore, the effects of straw returning and chemical $\mathrm{N}$ fertilization on soil ammonia oxidizers remain inconsistent; this may be attributed to different soil environments and cultivation measures.

Purple soil is the most representative soil-type in the Sichuan basin of south-western China. This soil is formed by rapid physical weathering of sedimentary rocks of the Trias-Cretaceous system and are characterized by lithologic soil without distinct pedogenic horizons. Purple soil is classified as Orthic Entisols, according to the Chinese soil taxonomic system, and as Regosols in the FAO taxonomy or Entisols in USDA taxonomic terms (Zhou et al. 2016). Moreover, purple soil has low content of organic carbon and available phosphorus and high potential fertility (Xiao et al. 2016; Wang et al. 2018), which makes it an important agronomic soil-type. Our previous results confirmed that straw mulching could reduce water evaporation and accumulate effective rainfall to meet the growth demand of winter wheat (Yang et al. 2020). However, the effects of years of straw mulch and nitrogen application on ammonia oxidizers on the alkaline purple soil in the hilly areas are unclear. In this study, we investigated the abundance and composition of ammonia oxidizers based on straw mulching and long-term fertilization of experimental fields. The objectives of this study were to (i) elucidate the implications of straw mulching with chemical $\mathrm{N}$ fertilization for alkaline purple soil fertility; (ii) identify the composition and abundance of ammonia oxidizers as well as the dominated and specific ammonia oxidizers in alkaline purple soil; and (iii) evaluate the relationships among the AOA and AOB communities, as well as soil properties. We hypothesized that straw mulching and application of $\mathrm{N}$ fertilization could cause changes in soil properties, which may result in shifts of ammonia oxidizers abundance and community composition.

\section{Materials and methods Study sites}

The straw mulch no-tillage location test started in 2015 and was carried out in Renshou experimental base (Fig. 1, 30 $04^{\prime} \mathrm{N}, 104^{\circ} 13^{\prime} \mathrm{E}$ ) of Agricultural College of Sichuan Agricultural University, China. The annual average temperature of this region is about $17.4{ }^{\circ} \mathrm{C}$ and mean annual precipitation is $1009.4 \mathrm{~mm}$. Moreover, this area is known for rain-fed agriculture, with most of the precipitation falling between April and September with a marked dry season between October and March (Du et al. 2013), with more rain for summer maize and less for winter wheat. The physical and chemical properties $(0-20 \mathrm{~cm})$ at the start of the experiment in 2015 were as follows: $\mathrm{pH}, 7.82$ (soil: water $=1: 2.5$ ); organic carbon, $9.78 \mathrm{~g} \mathrm{~kg}^{-1}$; total nitrogen, $0.83 \mathrm{~g} \mathrm{~kg}^{-1}$; total phosphorus, $0.86 \mathrm{~g} \mathrm{~kg}^{-1}$; total potassium, $13.96 \mathrm{~g} \mathrm{~kg}^{-1}$.

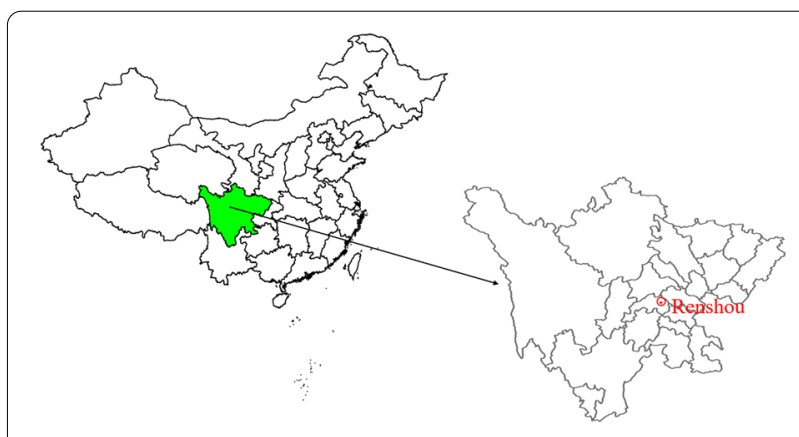

Fig. 1 Location of the study area 


\section{Sampling}

The experiment was laid out in a split plot design, with straw mulch as the main factor and nitrogen level as the sub-plot. Each treatment was replicated three times and the plot size was $30 \mathrm{~m}^{2}(6 \mathrm{~m} \times 5 \mathrm{~m})$. We selected maize straw mulching at rates of 6000 (S1) $\mathrm{kg} \mathrm{ha}^{-1}$ for experimental plot and 0 (SO) $\mathrm{kg} \mathrm{ha}^{-1}$ for control plot, and $\mathrm{N}$ fertilization at rates of 0 (N0), $120(\mathrm{~N} 1)$, and 180 (N2) $\mathrm{kg} \mathrm{N} \mathrm{ha}^{-1}$ under combined $\mathrm{P}$ and $\mathrm{K}$ fertilization, at $75 \mathrm{~kg} \mathrm{P}_{2} \mathrm{O}_{5} \mathrm{ha}^{-1}$ and $75 \mathrm{~kg} \mathrm{~K}_{2} \mathrm{O} \mathrm{ha}^{-1}$, respectively. Wheat harvest tillage horizon $(0-20 \mathrm{~cm})$ from plots were collected by S-shaped 5-point sampling method for one soil sample using a stainless-steel soil sampler with a diameter of $20 \mathrm{~cm}$ on 1st May, 2018. The sampling tool was a soil auger which had been rinsed with alcohol and deionized water. Then the roots and stones $(>2 \mathrm{~mm}$ ) were removed from the samples. Every plot was carefully mixed to form a composite sample and transported to the laboratory in a constant-temperature box containing ice. One part of each soil sample was stored at $-80{ }^{\circ} \mathrm{C}$ until DNA extraction, and others were dried under natural conditions.

\section{Soil properties}

All chemical analyses were based on air-dried soil. The $\mathrm{pH}$ was determined on a 1:2.5 soil/water mixture. The SOC was determined using potassium dichromate oxidation external heating method; soil TN and available nitrogen (AN) were determined using the alkaline hydrolysis diffusion method and semi-micro Kjeldahl method, respectively (Lu 1999). Soil available phosphorus (AP) was extracted using sodium bicarbonate and measured using the molybdenum blue method (Lu 1999). Soil available potassium (AK) was extracted using ammonium acetate and determined with flame photometry (P7 Double Beam UV-Visible Spectrophotometer; MAPADA Inc. Shanghai, China) (Lu 1999). Soil extractable ammonium $\left(\mathrm{NH}_{4}^{+}\right)$and nitrate $\left(\mathrm{NO}_{3}^{-}\right)$were extracted with $2 \mathrm{~mol} \mathrm{~L}^{-1} \mathrm{KCl}$ and determined colorimetrically (Singh et al. 2010).

\section{DNA extraction and quantitative real-time PCR amplification}

Total DNA was extracted from $0.5 \mathrm{~g}$ of soil using Fast DNA Spin Kit for Soil (MP Inc. CA, USA), following the manufacturer's instructions and stored at $-20{ }^{\circ} \mathrm{C}$. The amoA gene primers of AOA were Arch-amoAF (5'STAATGGTCTGGCTTAGACG-3') and Arch-amoAR (5'-GCGGCCATCCATCT-GTATGT-3') (Francis et al. $2005)$, and the $a m o A$ gene primers of $\mathrm{AOB}$ were $a m o A$ 1F (5'-GGGGTTTCTACTGGTGGT-3') and amoA-2R (5'-CCCCTCKGSAAAGCCTTCT-TC-3') (Cytryn et al.
2012). The qPCR was performed with ABI7500 Fast RealTime PCR System (Applied Biosystems Inc. USA). Each reaction containing $12.5 \mu \mathrm{L}$ of the SYBR Green Master Mix (Applied Biosystems, USA), $0.5 \mu \mathrm{L}(10 \mu \mathrm{M})$ of each primer, $1 \mu \mathrm{L}(20 \mathrm{ng} / \mu \mathrm{L})$ DNA template and $10.5 \mu \mathrm{L}$ of sterile water were used to make up a final volume of $25 \mu \mathrm{L}$. The procedure included an initial denaturation at $95{ }^{\circ} \mathrm{C}$ for $30 \mathrm{~s}$, and then 40 cycles at $95{ }^{\circ} \mathrm{C}$ for $15 \mathrm{~s}$, and $45 \mathrm{~s}$ at $55{ }^{\circ} \mathrm{C}$ (archaea) $/ 60{ }^{\circ} \mathrm{C}$ (bacteria), $72{ }^{\circ} \mathrm{C}$ for $45 \mathrm{~s}$. PCR products of AOB and AOA amoA gene were purified using PCR Purification Kit (Tiangen Biotech, Beijing, China), and then cloned using pClone007 Blunt Simple Vector Kit (Tsingke Biotech, Beijing, China), and the right gene inserts were chosen after sequencing and BLAST in GenBank on the NCBI's homepage (https:// blast.ncbi.nlm.nih.gov/Blast.cgi) to serve as standards and positive controls. The standard plasmids were quantified using a Nanodrop-2000 Spectrophotometer (NanoDrop Technologies, Wilmington, DE, USA).

The standard curves for amo $A$ were created using a tenfold dilution series $\left(10^{8}-10^{2}\right.$ copies) of the plasmids containing the targeted gene fragments from the soil. The standards and the DNA samples were analysed on the same plate. No amplification was detected in the negative control without template DNA. The qPCR was performed in duplicates and the efficiencies ranged from 94 to $110 \%$, one sharp peak was observed in the melting curve for the amoA standard, and the $\mathrm{R}^{2}$-values of the standards were higher than 0.98. CT (Cycle Threshold) values were used to calculate the numbers of $\mathrm{AOB}$ and AOA amoA gene abundance according to Harter et al. (2014). PCR inhibitors in soil DNA extracts were examined by diluting soil crude DNA. Inhibition was not detected in any of the controls.

\section{Terminal restriction fragment length polymorphism (T-RFLP) analysis of the bacterial and archaeal amoA genes} The T-RFLP analysis of the $a m o A$ genes was used to determine both bacterial and archaeal ammonia-oxidizers community composition. The same primers of qPCR were used in the T-RFLP analyses, and each forward primer was labelled with 6-carboxyfluorescein (FAM). The PCR reaction was performed in a $25 \mu \mathrm{L}$ volume containing $12.5 \mu \mathrm{L}$ of $2 \times$ Taq PCR Master Mix (Tiangen Biotech, Beijing, China), $0.5 \mu \mathrm{L}(5 \mu \mathrm{M})$ of each primer, $1 \mu \mathrm{L}$ DNA template $(20 \mathrm{ng} / \mu \mathrm{L})$, and $10.5 \mu \mathrm{L}$ of $\mathrm{ddH}_{2} \mathrm{O}$. The PCR protocols for both bacterial and archaeal amo $A$ genes were replicated three times using the following programs: $5 \mathrm{~min}$ at $94^{\circ} \mathrm{C}$ for initial denaturing, followed by 35 cycles of $94{ }^{\circ} \mathrm{C}$ for $30 \mathrm{~s}, 55{ }^{\circ} \mathrm{C}$ for $45 \mathrm{~s}$, and $72{ }^{\circ} \mathrm{C}$ for $45 \mathrm{~s}$ with the final extension for $10 \mathrm{~min}$ at $72{ }^{\circ} \mathrm{C}$. After amplification, the triplicate PCR reactions were pooled and purified using the PCR cleanup Kit (Axygen Biosciences, 
Union City, CA, USA). The purification PCR products were digested with 10 units of restriction enzyme $\mathrm{MboI}$ (TaKaRa) at $37{ }^{\circ} \mathrm{C}$ for $6 \mathrm{~h}$ and then denatured at $80{ }^{\circ} \mathrm{C}$ for $30 \mathrm{~min}$. The T-RFLP profiles were generated by capillary electrophoresis using an ABI Prism 3100 Genetic Analyser at Sangong Corporation (Shanghai, China). The T-RFLP lengths ranged from 50 to $500 \mathrm{bp}$ in size were considered for the further analyses. The peak heights of terminal restriction fragments (T-RFs) with size differences $\leq 2 \mathrm{bp}$ in an individual profile were combined and considered to be one fragment. The T-RFs with a relative abundance $<1 \%$ were excluded from further analysis.

\section{Clone, sequencing, and phylogenetic analysis of bacterial and archaeal $a m o A$ genes}

To identify the main T-RFs of the AOB and AOA TRFLP profiles, bacterial and archaeal $a m o A$ genes clone libraries were constructed using the same primers as T-RFLP but without the 6-FAM label. PCR-generated amoA fragments from soil DNA were excised from agarose gels and purified using the DNA Purification Kit (Tiangen Biotech, Beijing, China), followed by molecular cloning with a pClone007 Blunt Simple Vector Kit (Tsingke Biotech, Beijing, China) into Trelief ${ }^{\mathrm{TM}} 5 \alpha$ Chemically Competent Cell (Tsingke Biotech, Beijing, China). Screening for the correct size inserts was performed by PCR with M13 forward and reverse primers (Tiangen Biotech, Beijing, China). A total of 180 positive clones (approximately 30 clones from each treatments) were randomly selected for restriction screening (restriction enzymes: $M b o I$ ), and 49 typical clones were sequenced. The obtained sequences with more than $97 \%$ identity with each other were grouped into the same operational taxonomic unit (OTU) using MOTHUR (Schloss et al. 2009). Only one representative sequence of each OTU was compared using BLAST. Typical sequence in our T-RFLP experiment and their related sequences obtained by BLAST were chosen to construct the neighbour-joining tree using MEGA version 5.0 (Tamura et al. 2013). The virtual digests with $M b o I$ were carried out on the sequences retrieved from the clone libraries to allow the assignment of phylogenetic identity to individual T-RFs.

\section{Statistical analyses}

The means and standard deviations of the soil physicochemical parameters and $a m o A$ gene diversities were performed with two-way analysis of variance (ANOVA). In the two-way tests, the significance level was $P<0.05$. Redundancy analysis (RDA) was performed to analyse the relationships between soil properties and T-RFLP profiles of bacterial and archaeal amoA genes, using the software package CANOCO 5.0. The clone sequences were aligned using ClustalX (Thompson et al. 1997), and a neighbour-joining tree was constructed using MEGA 5.0. Bootstrap analysis was used to estimate the reliability of the phylogenetic reconstruction (1000 replicates) (Tamura et al. 2011).

\section{Results}

\section{Soil physicochemical properties}

As shown in Fig. 2, soil pH was not significantly changed by straw mulching, nitrogen application, and their interaction. The soil organic carbon (SOC) content of straw mulch (S1) treated soil were $18.86 \mathrm{~g} \mathrm{~kg}^{-1}$, which was significantly higher than that under no straw mulching (S0) treatment of $10.46 \mathrm{~g} \mathrm{~kg}^{-1}(P<0.05)$, and the interaction between straw mulching and nitrogen application had no significant effect on the SOC content, while SOC content was significantly increased by nitrogen application compared with no nitrogen application $(P<0.05)$. The variation trend for total nitrogen (TN), available potassium (AK), available nitrogen (AN), available phosphorus (AP), and $\mathrm{NH}_{4}{ }^{+}-\mathrm{N}$ were similar to that of SOC. Available potassium (AK) content was significantly increased by straw mulching, nitrogen application, and their interaction $(P<0.05)$. The available nitrogen $(\mathrm{AN})$ content was significantly increased by increasing nitrogen application, with $83.93,87.22$, and $90.48 \mathrm{mg} \mathrm{kg}^{-1}$ for N0, N1, and N2 treatments, respectively. Although straw mulching with nitrogen application increased the available phosphorus (AP) content, the difference was not statistically significant. The content of $\mathrm{NO}_{3}{ }^{-} \mathrm{N}$ was lower in straw mulching than that in the control groups, which had increased by nitrogen application. In addition, the correlation analysis confirmed that $\mathrm{pH}$ was negatively significantly correlated with $\mathrm{TN}, \mathrm{AN}$, and $\mathrm{NH}_{4}{ }^{+} \mathrm{-N}(P<0.05)$, and there were significant or extremely significant positive relationships among SOC, TN, AN, $\mathrm{NH}_{4}{ }^{+}-\mathrm{N}$, and $\mathrm{AP}(P<0.01$, 0.05; Fig. 3).

\section{Abundances of archaeal and bacterial $a m o A$ genes}

The abundance of archaeal $a m o A$ genes in soil samples significantly increased from $6.87 \log 10$ per gram dry soil of the control (S0) to $7.77 \log 10$ per gram dry soil of the straw mulching (S1) groups $(P<0.05$, Fig. 4a). The increase of nitrogen fertilizer did not significantly influence the abundance of ammonia-oxidizing archaeal (AOA) in the sub-plot treatment. Interestingly, our results indicated that nitrogen application increased the AOA abundance in no straw mulching groups and decreased that in straw mulching groups. The combination of straw mulching and nitrogen on the significantly improved the AOA abundance $(P<0.05)$. Ammoniaoxidizing bacterial (AOB) abundance ranged from 6.64 $\log 10$ per gram dry soil of the control (S0) to $8.01 \log 10$ per gram dry soil of the straw mulching (S1) treatment 


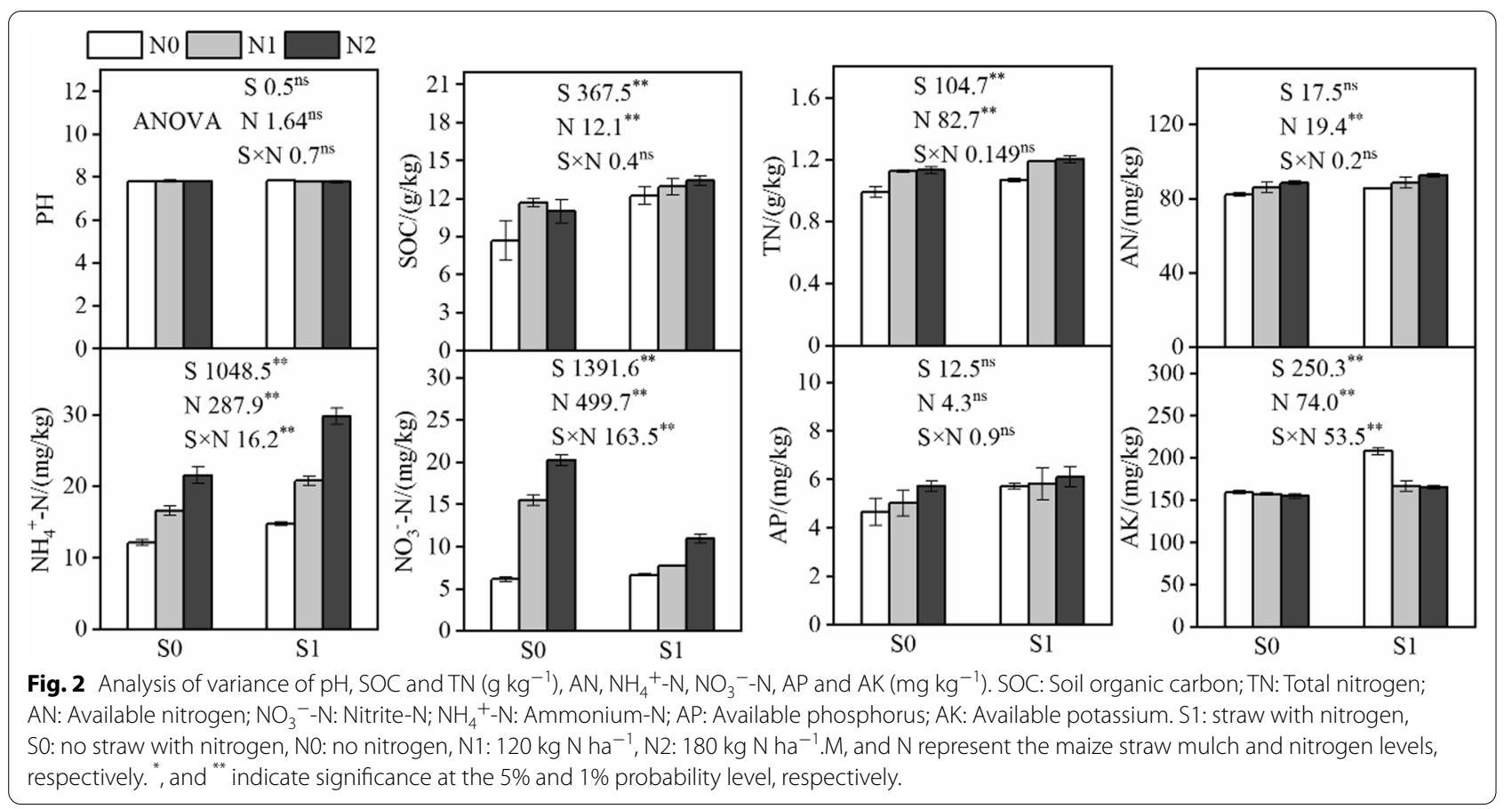

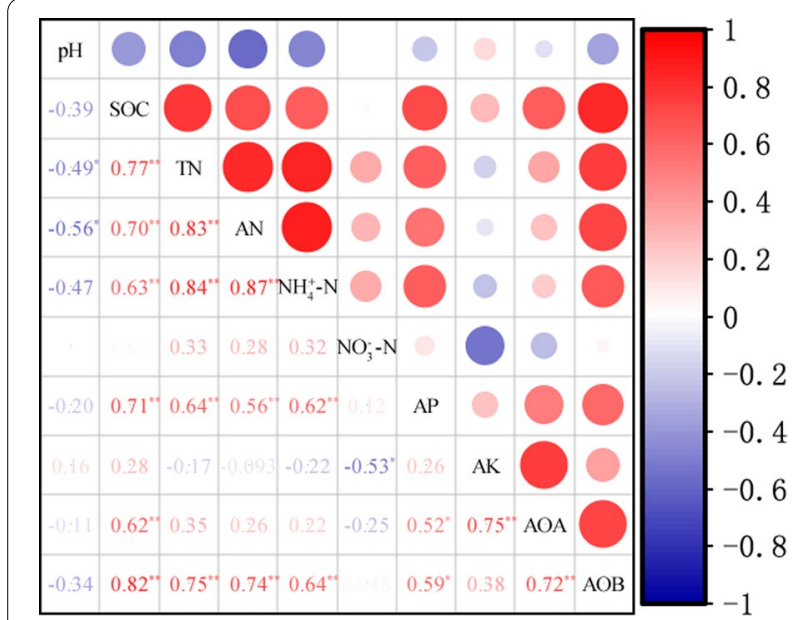

Fig. 3 Pearson correlation analyses of soil properties and $a m o A$ gene abundances of ammonia oxidation archaea (AOA) and bacteria (AOB). Red represents a positive correlation, blue represents a negative correlation, and the larger the circle, the darker the colour, the stronger the correlation. SOC: Soil organic carbon; TN: Total nitrogen; AN: Available nitrogen; $\mathrm{NO}_{3}{ }^{-}-\mathrm{N}$ : Nitrite- $\mathrm{N} ; \mathrm{NH}_{4}{ }^{+}-\mathrm{N}$ : Ammonium-N; AP: Available phosphorus; AK: Available potassium. * and ${ }^{* *}$ indicate significance correlation at the $5 \%$ and $1 \%$ probability level, respectively

$(P<0.05$, Fig. $4 \mathrm{~b})$, indicating that $\mathrm{AOB}$ abundance was significantly affected by the straw mulching, nitrogen application, and their interaction $(P<0.05)$. The ratios of AOA/AOB abundance ranged from 0.9 to 1.0 (Additional
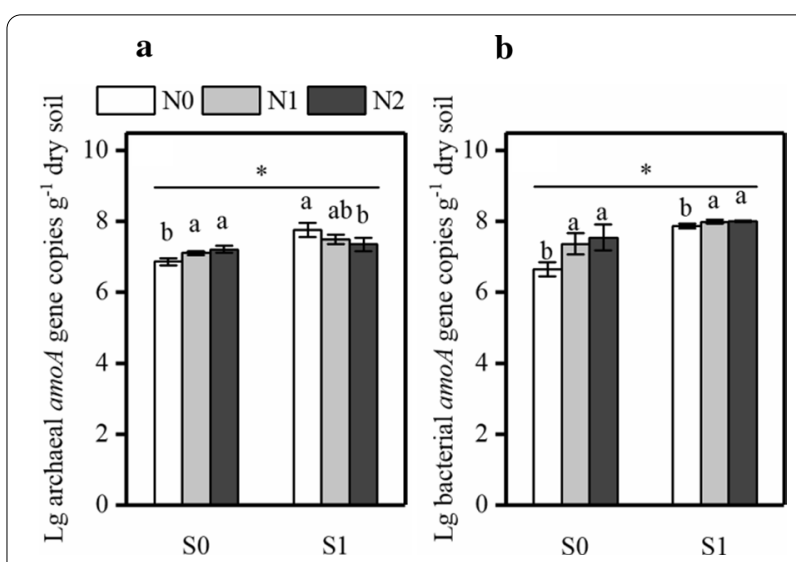

Fig. 4 The abundance of $a m o A$ gene copies of ammonia oxidation archaea (a) and bacteria (b) in the different treatments. Data were mean \pm S.D. S1: Straw with nitrogen, S0: no straw with nitrogen, N0: No nitrogen, $\mathrm{N1}: 120 \mathrm{~kg} \mathrm{~N} \mathrm{ha}^{-1}, \mathrm{N2}: 180 \mathrm{~kg} \mathrm{~N} \mathrm{ha}^{-1}{ }^{*}{ }^{*}$, and different letters indicate significate at the $5 \%$ probability level, respectively

file 1: Fig. S1), indicating that the AOA abundance was lower than that of $\mathrm{AOB}$ and $\mathrm{AOB}$ was dominated in the soil. Specifically, nitrogen treatment significantly increased the amo $A$ gene copies of AOB $(P<0.05$, Fig. $4 \mathrm{~b})$, therefore, the AOA abundance was less sensitive to nitrogen application than AOB. Importantly, the combination of straw mulching and nitrogen application resulted in a shift in the predominant ammonia-oxidizers from AOA to AOB. Pearson correlation analyses revealed 
that SOC, TN, AP, and AK significantly affected the abundance of AOA amoA gene $(P<0.05)$, and the abundance of $\mathrm{AOB}$ amoA gene was significantly affected by SOC, TN, AN, $\mathrm{NH}_{4}{ }^{+}-\mathrm{N}$ and AP $(P<0.05$, Fig. 3$)$.

\section{Compositions of the ammonia-oxidizing bacterial and archaeal communities}

The Terminal restriction fragment length polymorphism (T-RFLP) analysis of amoA gene showed that the ammonia-oxidizing bacterial and archaeal communities changed in the different treatments. Principal component analysis (PCA) shows that the community structure of AOA was differentiated into three clusters, SON0 as cluster 1, S1N0 as cluster 2, and other treatments as cluster 3 , which indicated that straw mulching and nitrogen application resulted in variations in the AOA community (Fig. 5a). The predominant T-RFs of the AOA were 448-, 427-, and 50-bp T-RFs in all groups, which accounted for $85 \%$, on average, of the total AOA community. Compared with the control (SON0, SON1, and SON2) groups, the straw mulching (S1N0, S1N1, and S1N2) groups showed higher relative abundances of 448- and 50-bp T-RFs. By contrast, the relative abundance of 427-bp T-RF was higher in the control groups. In addition, we found some common minor amoA T-RFs (<5\%). For example, the 54-bp T-RF had the highest abundance in straw mulching (S1N1), while the highest relative abundances of 90- and 93-bp T-RFs were observed in S0N1 (Fig. 5b). As for the AOB community composition, PCA showed clear differences in the effects of straw mulching and nitrogen application (Fig. 5c). The T-RFs of 285-, 111-, 82-, and 54-bp were dominant in all treatments. The relative abundances of 82-, 54- and 111-bp T-RFs were higher in S1N0 and S1N1, and the highest relative abundance of 285-bp T-RF was observed in S0N2. We found that the 79-bp T-RF was only detected in the control groups, indicating that straw mulching had a great impact on the composition of AOB community (Fig. 5d).

In the in silico T-RFLP analysis of the amo $A$ sequences obtained in this study and from the NCBI database, the ammonia oxidizers in the clone library were generally similar to those detected in the actual T-RFLP. The ammonia oxidation archaeal dominant T-RFs of 448-bp was consistent with Thaumarchaeote, the 54-, 93-, 139-, and 427-bp were consistent with Crenarchaeote. As for AOB, the dominant T-RFs of 111 bp was consistent with Nitrosospira sp, the 89 bp T-RF was consistent with Nitrosomonadales, and the T-RFs of 58- and 79-bp were consistent with $\beta$-proteobacterium.
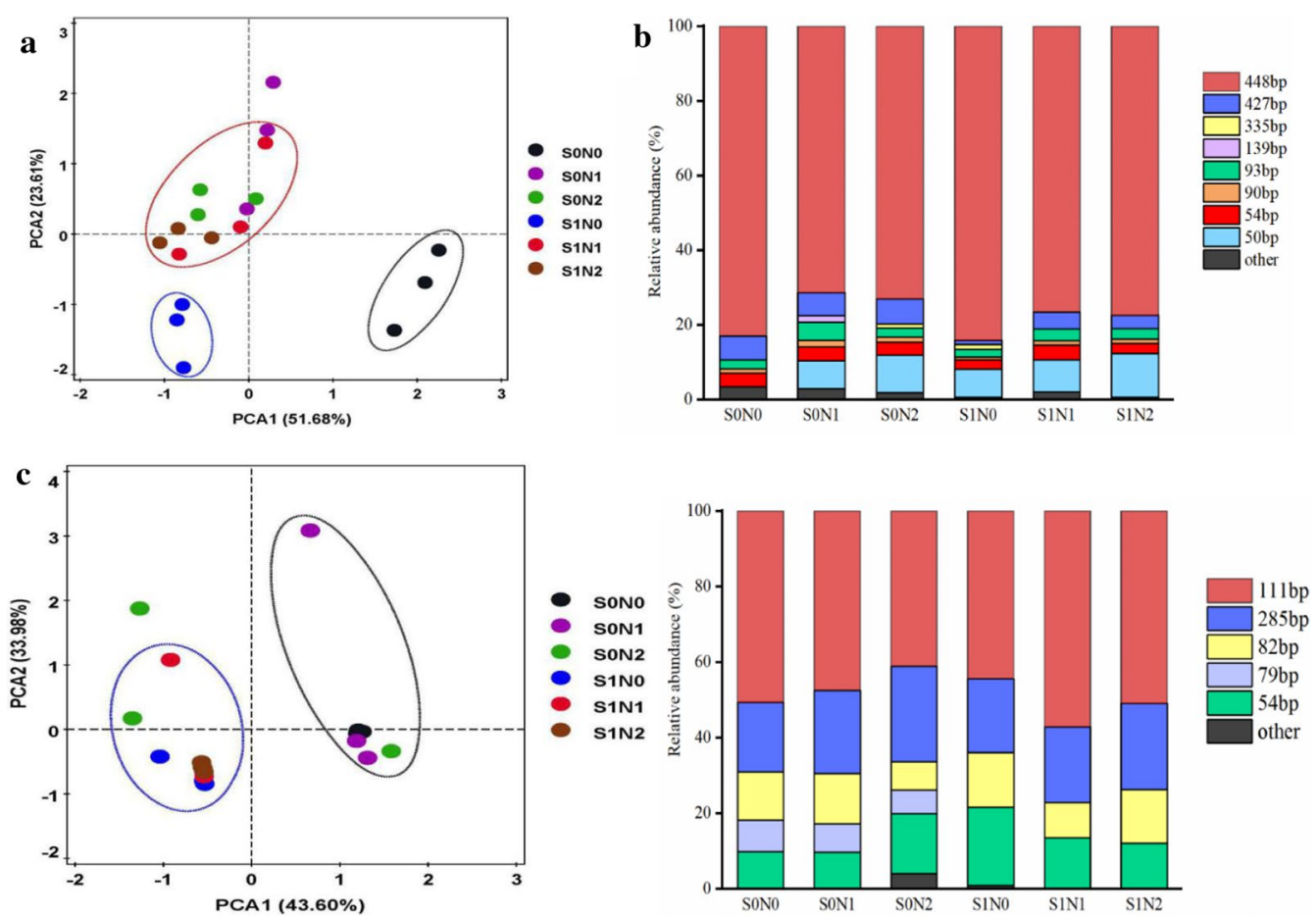

Fig. 5 Principal Component Analysis of ammonia oxidation archaeal (a) and bacterial (c) community and the relative abundance of T-RFs for ammonia oxidation archaeal $(\mathbf{b})$ and bacterial $(\mathbf{d})$ in different treatments. Data were mean \pm S.D. SONO: No straw mulching with no nitrogen, SON1: No straw mulching with $120 \mathrm{~kg} \mathrm{~N} \mathrm{ha}^{-1}$, SON2: No straw mulching with $180 \mathrm{~kg} \mathrm{~N} \mathrm{ha}^{-1}$, S1NO: Straw mulching with no nitrogen, S1N1: Straw mulching with $120 \mathrm{~kg} \mathrm{~N} \mathrm{ha}^{-1}$, S1N2: Straw mulching with $180 \mathrm{~kg} \mathrm{~N} \mathrm{ha}^{-1}$ 


\section{Phylogenetic analysis}

In the phylogenetic analysis, using the MOTHUR Program, sequences were grouped by OTUs with a 97\% similarity cut-off, resulting in 6 AOA OTUs and $11 \mathrm{AOB}$ OTUs, and the AOA amoA gene sequences were grouped into three clusters (Fig. 6). OTU2, OTU3, OTU5 and OTU6 as cluster 1, OTU1 as cluster 2, OTU4 as cluster 3 . In cluster 1 , the OTUs were similar with environmental clones from sediments, and OTU2 and OTU3 were detected in all treatments, while OTU5 was uniquely found in the straw mulching with high nitrogen treatment (S1N2), and OTU6 was detected in high nitrogen treatments (SON2 and S1N2). The OTUs that grouped into clusters 2 and 3 were similar to environmental clones from agricultural soils, and OTU1 was distributed across all the treatments, while OTU4 was uniquely found in S0N2 and S1N1 treatments (Fig. 6a; Additional file 1: Table S1). Moreover, the AOB amoA gene sequences were grouped into four clusters. OTU1 and OTU3 were related to Nitrosospira cluster, OTU5, OTU9, and OTU10 were affiliated with the cluster2, OTU2, OTU4, OTU6, OTU7, OTU8, and OTU11 were belong to the Nitrosomonadales cluster (Fig. 6b; Additional file 1: Table S2). Overall, the dominant AOB OTUs were affiliated with the Nitrosospira and Nitrosomonadales, and they were distributed across different treatments.

\section{Relationships of the ammonia oxidizers community compositions and soil properties}

The influences of soil properties under the different tillage regime distribution of $\mathrm{AOA}$ and $\mathrm{AOB}$ communities were evaluated using redundancy analysis (RDA; Fig. 7). Selected soil properties were used as environmental variables, and the T-RFs of AOA and AOB were used for analysing the communities of $\mathrm{AOA}$ and $\mathrm{AOB}$. For AOA, the first and second axes accounted for $44.46 \%$ and $15.10 \%$ of the total variation between soil properties and AOA community, respectively. The distribution of AOA T-RFs was significantly correlated with SOC, TN, AN, AP, and AK, as well as $\mathrm{NH}_{4}{ }^{+}-\mathrm{N}(P<0.05)$. Among the measured soil properties, SOC and TN were the highest contributors, accounting for $30.5 \%$ and $35.2 \%$, respectively (Fig. 7a; Additional file 1: Table S3). These were the key factors in shaping the AOA community composition. For AOB, the first and second axes accounted for $22.12 \%$ and $13.86 \%$ of the total variation between soil properties and AOB community, respectively. SOC and AP were significantly correlated with the distribution of AOB T-RFs $(P<0.05)$, and the contribution of SOC and AP were $39.7 \%$ and $35.6 \%$, respectively (Fig. 7b; Additional file 1: Table S4). These results suggested that $\mathrm{SOC}$ and $\mathrm{AP}$ were the major factors affecting the $\mathrm{AOB}$ community composition.

\section{Discussion}

Effects of straw mulching and nitrogen application on soil properties of alkaline purple soil

Previous study reported that purple soil had low content of SOC and AP (Xiao et al. 2016), and most of the phosphorus combined with $\mathrm{Ca}$ carbonate in alkaline soil, thereby reducing the availability of phosphorus ( $\mathrm{Li}$ et al. 2011). Straw returning with nitrogen fertilizer promoted the decomposition of straw and increased the SOC (Akhtar et al. 2019), thereby significantly improving soil health (Jha et al. 2020). In present study, both straw mulching and nitrogen application significantly increased SOC content in alkaline purple soil, which was possibly owing to the slow decomposition of straw (Naresh et al. 2018), and the increase in the nitrogen fertilizer level might promote soil carbon sink, which could have resulted from the increase in aboveground biomass, especially the increase of root biomass (Rasse et al. 2005). Meanwhile, our results show that straw mulching slightly increased the content of AP. In addition, many studies have shown that tillage practices and stubble management play an important role in the soil nitrogen pool. No tillage with straw mulching increased the TN content of the topsoil and affected soil nitrogen cycle (Ye et al. 2019). In present study, straw mulching treatment resulted in a $6.60 \%$ and $4.01 \%$ increase in TN and AN content, respectively. The reason may be that the large amount of SOC released by the decomposition of straw, which increased labile organic $\mathrm{C}$ and $\mathrm{N}$ and eased the nutrient limitation of microorganisms, further increased the transformation of soil nitrogen (Dong et al. 2019). The present study found the contents of $\mathrm{NH}_{4}{ }^{+}-\mathrm{N}$ and $\mathrm{NO}_{3}{ }^{-} \mathrm{N}$ in straw mulching groups decreased significantly during wheat harvest compared with the no straw mulching groups. Therefore, no tillage with straw mulching significantly reduced the content of mineral nitrogen in the surface soil and slowed down the deep accumulation of nitrate nitrogen in the soil to a certain extent (Ye et al. 2019; Dong et al. 2019). The present study also confirmed that straw mulching and fertilization increased the content of AK. Moreover, SOC, TN, AN, $\mathrm{NH}_{4}{ }^{+}-\mathrm{N}$ and AP contents were positively correlated with each other. In summary, straw mulching and nitrogen application is an effective and sustainable management practice to improve soil fertility comprehensively in alkaline purple soil.

\section{$a m o A$ gene abundance in response to years of straw mulching and fertilization}

Previous studies have provided evidence that $\mathrm{AOB}$ and AOA functionally dominated the nitrification process in agricultural soil, and the $a m o A$ gene copy numbers of archaea and bacteria were highly associated with 


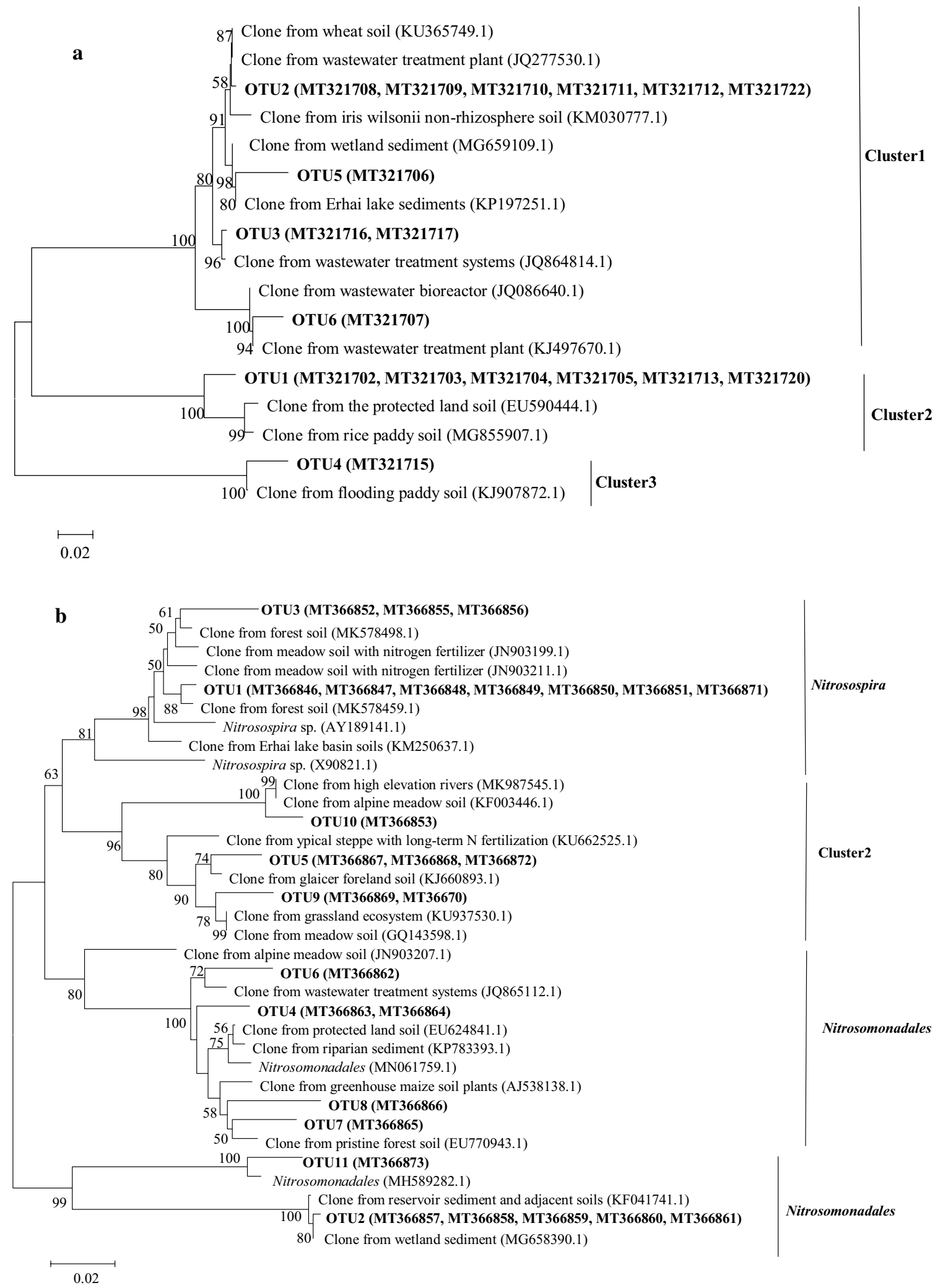

Fig. 6 Neighbor-joining trees based on partial archaeal amoA genes (a) and bacterial amoA genes (b). Names of sequences obtained in this study are marked in bold, the numbers in parenthesizes are their respective T-RF sizes belonging to the OTU. Bootstrap analysis of 1000 replicates values are shown next to each node 

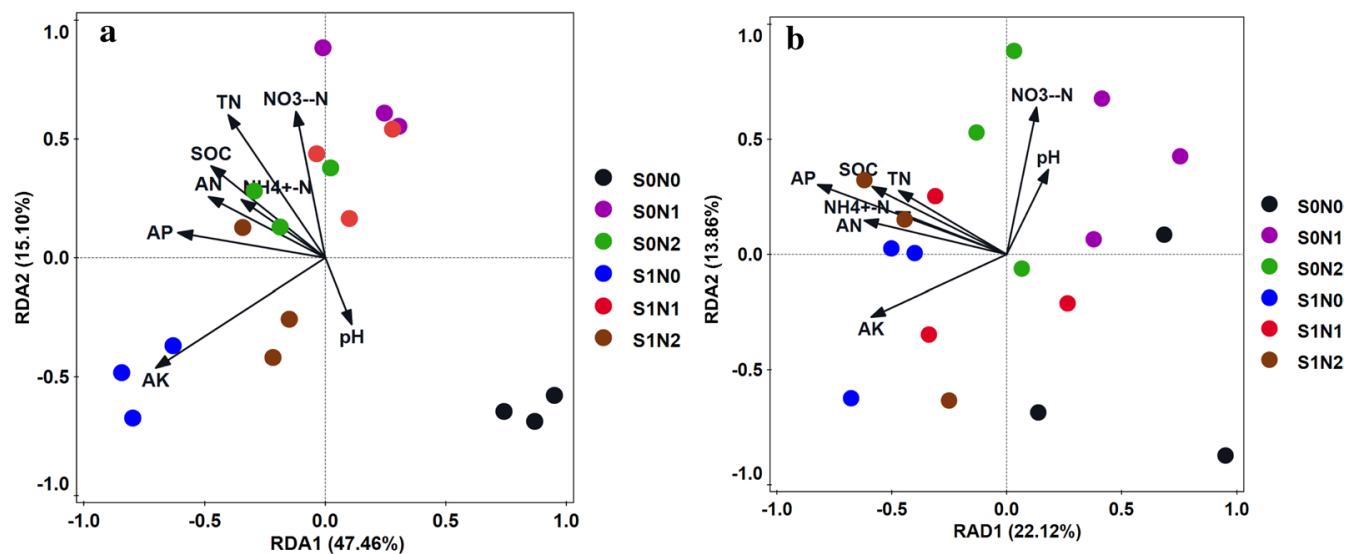

Fig.7 Redundancy analysis (RDA) of the correlation of soil properties with AOA community structure (a) and AOB community structure (b). SONO: No straw mulching with no nitrogen, SON1: No straw mulching with $120 \mathrm{~kg} \mathrm{~N} \mathrm{ha}^{-1}$, SON2: No straw mulching with $180 \mathrm{~kg} \mathrm{~N} \mathrm{ha}{ }^{-1}$, S1 NO: Straw mulching with no nitrogen, S1N1: Straw mulching with $120 \mathrm{~kg} \mathrm{~N} \mathrm{ha}^{-1}$, S1N2: Straw mulching with $180 \mathrm{~kg} \mathrm{~N} \mathrm{ha}^{-1}$

ammonia oxidation activity (Offre et al. 2009). Thus, quantification of gene abundance of $\mathrm{AOA}$ and $\mathrm{AOB}$ under the long-term field fertilization and straw mulching could reflect how $\mathrm{N}$ is being transformed and the pathways of potential $\mathrm{N}$ loss in agricultural systems (Munroe et al. 2016). Some studies had shown that the abundance of AOA and AOB shift in response to fertilization, tillage, and other environmental factors (Segal et al. 2017; Liu et al. 2018). Shen et al. (2008) found that fertilizer type might not be a factor in determining AOA abundance in alkaline soil, while long-term fertilizer treatments influenced AOA abundance in an acidic soil (He et al. 2007). The AOA abundance was found to be influenced by the addition of straw, but the AOB abundance varied little, in contrast to that of the AOA (Wessén et al. 2010). In present study, the abundance of both AOA and AOB in alkaline purple soil were increased by straw mulching. We also found that nitrogen application had significant effect on the abundance of $\mathrm{AOB}$, which is consistent with previous findings (Zhou et al. 2014). Other studies indicated that the abundance of AOA was usually higher than that of $\mathrm{AOB}$ in alkaline sandy loam and purple soil (Shen et al. 2008; Zhou et al. 2016). However, our study results found that the abundance of $\mathrm{AOB}$ was higher than that of AOA after straw mulching and nitrogen application, while lower in no straw mulching with no nitrogen group, indicating that straw mulching and nitrogen application resulted in a shift in the predominant ammonia-oxidizers from $A O A$ to $A O B$ in alkaline purple soil, which may be related to the change of soil properties caused by straw mulching and nitrogen application.

\section{Ammonia oxidizer community compositions in response to years of straw mulching and fertilization}

Although the AOA and AOB communities were significantly related to the agronomic management, their responses were different and varied greatly under different farming and fertilization systems (Segal et al. 2017; Liu et al. 2018). Wang et al. (2017) suggested that the application of different fertilizers had a great impact on soil AOB community compositions, while the fertilization system had a weaker impact on the composition of AOA community. However, some studies showed that AOA composition is sensitive to different fertilization regimes (He et al. 2007; Wessén et al. 2010), this might be influenced by agricultural management, climate and geographic conditions (Wang et al. 2017). In our study, the core of the AOA community in the different treatments were similar, yet more minor T-RFs were detected in the no straw mulching groups and the nitrogen application groups had their specific minor T-RFs (Fig. 5). This suggested that straw mulching could affect AOA community composition, and the minor T-RFs contributed to the community structural differences in alkaline purple soil. Presumably due to some AOA can use carbon dioxide as sole carbon source, so organic carbon sources have major influence on the AOA communities (Zhalnina et al. 2012). However, the dominant T-RFs contributed to the structural differences in the $\mathrm{AOB}$ community as both straw mulching and the application of nitrogen fertilizers had a great impact on soil AOB community composition in present study (Fig. 5). This suggested that the AOB was more responsive than AOA to the straw mulching and the application of nitrogen fertilizers in alkaline purple soil (Shen et al. 2008; Ai et al. 2013). 
The phylogeny of the amoA gene has been used to study the community shifts and provide valuable additional information in many studies. For AOA, a pronounced different composition of AOA was observed in our study. Cluster 1 with the sequences retrieved from NCBI were closely related to cluster water and sediment, and cluster 2 were related to cluster soil as reported by previous studies (Francis et al. 2005). Cluster 3 and cluster 4 dominated exclusively in the application of nitrogen treatments, indicating that fertilizer supplies shifted the composition of AOA in alkaline purple soil ( $\mathrm{He}$ et al. 2007). In addition, we found that the most dominant OTUs of AOA were affiliated with Thaumarchaeote. Previous studies found that the AOB members within Nitrosospira or Nitrosomonadales clusters were highly sensitive to fertilization, for example, the AOB related to Nitrosospira (Shen et al. 2008). Cluster 3 is highly enriched in the fertilized soil, and were most common in agricultural fields (Shen et al. 2008). However, previous studies have also reported that Nitrosospira are dominant in relatively low $\mathrm{N}$ environments (Ke et al. 2013). Our results showed that Nitrosospira dominated in the different treatments, which was consistent with previous research (Phillips et al. 2000).

\section{Relationships between community compositions, abundance of ammonia oxidizers, and soil properties}

AOA and AOB communities are affected by multiple edaphic factors (de Gannes et al. 2014; Wang et al. 2017). Previous studies suggested that soil $\mathrm{pH}$ is an important factor affecting the community compositions of ammonia oxidizers (Zhou et al. 2016). However, the present study found that the composition of AOA significantly correlated with most measured soil properties, such as SOC, TN, AN, AP, $\mathrm{NH}_{4}{ }^{+}-\mathrm{N}$, and AK. This explained how straw mulching increases SOC, thereby providing a constant source of substrate for growth and activity of archaeal ammonia oxidizers (Stopnisek et al. 2010). Although de Gannes et al. (2014) proposed that soil $\mathrm{N}$ characteristics of ammonium-N and organic $\mathrm{N}$ pools were the major factors affecting AOA communities, and ammonium- $\mathrm{N}$ as the substrate provided energy for ammonia oxidizers. It has been suggested that AOA has a higher affinity for ammonium/ ammonia and, hence, grow widely at different ammonia concentrations (Zhalnina et al. 2012). In addition, some studies shown that soil $\mathrm{P}$ level was the variable which affected the communities of both $\mathrm{AOA}$ and $\mathrm{AOB}$, and it was much more significant for the AOB under exogenous P application (Fierer et al. 2009). Our results showed that SOC and AP significantly related to the AOB communities, which might be the key factors affecting the $\mathrm{AOB}$ communities. In addition, our results confirmed that the soil $\mathrm{pH}$ did not significantly corrected with the abundance and community compositions of ammonia oxidizers, while the SOC and AP did. Moreover, the effect of soil factors on the abundance and community compositions of ammonia oxidizers was inconsistent. Such as the community compositions of AOA were significantly correlated with soil nitrogen ( $\mathrm{TN}, \mathrm{AN}$, and $\mathrm{NH}_{4}{ }^{+}-\mathrm{N}$ ) and $\mathrm{AK}$, while the abundance of AOA correlated significantly AK, and the abundance of AOB correlated significantly soil nitrogen $(\mathrm{TN}, \mathrm{AN}$, and $\mathrm{NH}_{4}{ }^{+}-\mathrm{N}$ ).

In conclusion, the present study revealed that straw mulching and nitrogen application changed the abundance and composition of ammonia oxidizers and improved the ability to provide nutrients in alkaline purple soil. SOC and AP were critical to the abundance and community compositions of $\mathrm{AOA}$ and $\mathrm{AOB}$ in alkaline purple soil. Thaumarchaeote and Nitrosospira sp were the dominant ammonia oxidizers in alkaline purple soil. This information is useful for assessing the sustainability of agricultural management strategies and soil quality.

\section{Supplementary Information}

The online version contains supplementary material available at https://doi. org/10.1186/s13568-021-01211-x.

Additional file 1: Table S1. The numbers of archaral amoA OTUs in different straw mulching and fertilization treatments. Table S2. The numbers of bacterial amoA OTUs in different straw mulching and fertilization treatments. Table S3. The statistical significance of archaeal community with soil physicochemical properties by redundancy analysis (RDA) in different treatments. Table S4. The statistical significance of bacterial community with soil physicochemical properties by redundancy analysis (RDA) in different treatments. Fig.S1. The abundance of amoA gene copies of ammonia oxidation archaea ratio bacteria in the different treatments. Data were mean \pm S.D. S1: straw with nitrogen, S0: no straw with nitrogen, N0: no nitrogen, N1: $120 \mathrm{~kg} \mathrm{~N} \mathrm{ha}^{-1}$, N2: $180 \mathrm{~kg} \mathrm{~N} \mathrm{ha}^{-1} . \mathrm{M}$, and $\mathrm{N}$ represent the maize straw mulch and nitrogen levels, respectively.

\section{Acknowledgements}

The authors would like to acknowledge College of Agronomy, Sichuan Agricultural University, for supporting our study.

\section{Authors' contributions}

$\mathrm{FQ}$ and $\mathrm{CH}$ designed the study. $\mathrm{CH}$ interpreted the results. $\mathrm{CH}, \mathrm{GR}, \mathrm{XL}, \mathrm{ML}$, $\mathrm{ZT}, \mathrm{XY}, \mathrm{ZX}$ and $\mathrm{LH}$ performed the experiments. $\mathrm{CH}$ and $\mathrm{XL}$ participated in writing the manuscript. $Y Y$ and $Y K$ supervised the study. All authors read and approved the final manuscript.

\section{Funding}

The study was funded by the Special Fund for National key research and development program (Grant Number 2016YFD0300406, 2016) and Agroscientific Research in public interest (Grant Number 20150312705, 2015).

\section{Availability of data and materials}

The sequenced archaeal and bacterial $a m o A$ gene sequences were deposited in the GenBank database with the accession numbers MT321702-MT321722 and MT366846-MT366873, respectively. 


\section{Declarations}

Ethics approval and consent to participate

Not applicable.

\section{Consent for publication}

Not applicable.

\section{Competing interests}

The authors declare that they have no competing interests.

Received: 10 November 2020 Accepted: 22 March 2021

Published online: 07 April 2021

\section{References}

Ai C, Liang GQ, Sun JW, Wang XB, He P, Zhou W (2013) Different roles of rhizosphere effect and long-term fertilization in the activity and community structure of ammonia oxidizers in a calcareous fluvo-aquic soil. Soil Biol Biochem 57:30-42

Akhtar K, Wang WY, Ren GG, Khan A, Feng YZ, Yang GH, Wang HY (2019) Integrated use of straw mulch with nitrogen fertilizer improves soil functionality and soybean production. Environ Int 132:105092

Cytryn E, Levkovitch I, Negreanu Y, Dowd S, Frenk S, Silber A (2012) Impact of short-term acidification on nitrification and nitrifying bacterial community dynamics in soilless cultivation media. Appl Environ Microb 78:6576-6582

de Gannes V, Eudoxie G, Hickey WJ (2014) Impacts of edaphic factors on communities of ammonia-oxidizing archaea, ammonia-oxidizing bacteria and nitrification in tropical soils. PLoS ONE 9:e89568

Di HJ, Cameron KC, Shen JP, Winefield CS, O'callaghan M, Bowatte S, He JZ, (2009) Nitrification driven by bacteria and not archaea in nitrogen-rich grassland soils. Nat Geosci 2:621-624

Dong Q, Dang TH, Guo SL, Hao MD (2019) Effects of mulching measures on soil moisture and $\mathrm{N}$ leaching potential in a spring maize planting system in the southern Loess Plateau. Agr Water Manage 213:803-808

Du J, Luo YJ, Zhang WH, Xu C, Wei CF (2013) Major element geochemistry of purple soils/rocks in the red Sichuan basin, China: implications of their diagenesis and pedogenesis. Environ Earth Sci 69:1831-1844

Fierer N, Carney KM, Horner-Devine MC, Megonigal JP (2009) The biogeography of ammonia-oxidizing bacterial communities in soil. Microb Ecol 58:434-445

Francis CA, Roberts KJ, Beman JM, Santoro AE, Oakley BB (2005) Ubiquity and diversity of ammonia-oxidizing archaea in water columns and sediments of the ocean. Pro Natl Acad Sci USA 102:14683-14688

Harter J, Krause HM, Schuettler S, Ruser R, Fromme M, Scholten T, Kappler A, Behrens $\mathrm{S}$ (2014) Linking $\mathrm{N}_{2} \mathrm{O}$ emissions from biochar-amended soil to the structure and function of the $\mathrm{N}$-cycling microbial community. The ISME J 8:660-674

He JZ, Shen JP, Zhang LM, Zhu YG, Zheng YM, Xu MG, Di H (2007) Quantitative analyses of the abundance and composition of ammonia-oxidizing bacteria and ammonia-oxidizing archaea of a Chinese upland red soil under long-term fertilization practices. Environ Microbiol 9:2364-2374

Hu QY, Liu TQ, Jiang SS, Cao CG, Li CF, Chen B, Liu JB (2019) Combined effects of straw returning and chemical $\mathrm{N}$ fertilization on greenhouse gas emissions and yield from paddy fields in northwest Hubei province China. J Soil Sci Plant Nut. 16:1-15

Jha P, Hati KM, Dalal RC, Dang YP, Kopittke PM, Menzies NW (2020) Soil carbon and nitrogen dynamics in a Vertisol following 50 years of no-tillage, crop stubble retention and nitrogen fertilization. Geoderma 358:113996

Ke X, Angel R, Lu Y, Conrad R (2013) Niche differentiation of ammonia oxidizers and nitrite oxidizers in rice paddy soil. Environ Microbiol 15:2275-2292

Li H, Huang G, Meng Q, Ma L, Yuan L, Wang F, Zhang W, Cui Z, Shen J, Chen X, Jiang R, Zhang F (2011) Integrated soil and plant phosphorus management for crop and environment in China. A review. Plant Soil 349:157-167

Li H, Weng B, Huang F, Su J, Yang X (2015) pH regulates ammonia-oxidizing bacteria and archaea in paddy soils in southern China. Appl Microbiol Biot 99:6113-6123
Liu S, Hu B, He Z, Zhang B, Tian G, Zheng P, Fang F (2015) Ammonia-oxidizing archaea have better adaptability in oxygenated/hypoxic alternant conditions compared to ammonia-oxidizing bacteria. Appl Microbiol Biot 99:8587-8596

Liu HY, Li J, Zhao Y, Xie KX, Tang XJ, Wang SX, Li ZP, Liao YL, Xu JM, Di HJ, Li Y (2018) Ammonia oxidizers and nitrite-oxidizing bacteria respond differently to long-term manure application in four paddy soils of south of China. Sci Total Envirom 633:641-648

Liu HY, Li J, Zhao Y, Xie KX, Tang XJ, Wang SX, Li ZP, Liao YL, Xu JM, Di HJ, Li Y (2019) Ammonia oxidizers and nitrite-oxidizing bacteria respond differently to long-term manure application in four paddy soil of south of China. Sci Total Environ 633:641-648

Lu RK (1999) Soil and agrochemical analytical methods. China Agricultural Science and Technology Press Beijing, China, pp 146-195

Munroe JW, Mccormick I, Deen W, Dunfield KE (2016) Effects of 30 years of crop rotation and tillage on bacterial and archaeal ammonia oxidizers. J Environ Qual 45:940-948

Naresh PK, Jat PC, Kumar V, Singh SP, Kumar Y (2018) Carbon and nitrogen dynamics, carbon sequestration and energy saving in soils under different tillage, stubble mulching and fertilizer management in rice-wheat cropping system. J Pharmaco Phytochem 7:723-740

Offre P, Prosser Jl, Nicol GW (2009) Growth of ammonia-oxidizing archaea in soil microcosms is inhibited by acetylene. FEMS Microbiol Ecol 70:99-108

Phillips CJ, Harris D, Dollhopf SL, Gross KL, Prosser Jl, Paul EA (2000) Effects of agronomic treatments on structure and function of ammonia-oxidizing communities. Appl Environ Microb 66:5410-5418

Rasse DP, Rumpel C, Dignac MF (2005) Is soil carbon mostly root carbon? Mechanisms for a specific stabilisation. Plant Soil 269:341-356

Schloss PD, Westcott SL, Ryabin T, Hall JR, Hartmann M, Hollister EB, Lesniewski RA, Oakley BB, Parks DH, Robinson CJ, Sahl JW, Stres B, Thallinger GG, Van Horn DJ, Weber CF (2009) Introducing mothur: open-source, platformindependent, community-supported software for describing and comparing microbial communities. Appl Environ Microb 75:7537-7541

Segal LM, Miller DN, McGhee RP, Loecke TD, Cook KL, Shapiro CA, Drijber RA (2017) Bacterial and archaeal ammonia oxidizers respond differently to long-term tillage and fertilizer management at a continuous maize site. Soil Till Res 168:110-117

Shen JP, Zhang LM, Zhu YG, Zhang JB, He JZ (2008) Abundance and composition of ammonia-oxidizing bacteria and ammonia-oxidizing archaea communities of an alkaline sandy loam. Environ Microbiol 10:1601-1611

Singh BK, Bardgett RD, Smith P, Reay DS (2010) Microorganisms and climate change: terrestrial feedbacks and mitigation options. Nat Rev Microbiol 8:779-790

Stopnisek N, Gubry-Rangin C, Höfferle S, Nicol GW, Mandic-Mulec I, Prosser I (2010) Thaumarchaeal ammonia oxidation in an acidic forest peat soil is not influenced by ammonium amendment. Appl Microbiol Biot 76:7626-7634

Tamura K, Peterson D, Peterson N, Stecher G, Nei M, Kumar S (2011) MEGA5: molecular evolutionary genetics analysis using maximum likelihood, evolutionary distance, and maximum parsimony methods. Mol Biol Evol 28:2731-2739

Tamura K, Stecher G, Peterson D, Filipski A, Kumar S (2013) MEGA6: molecular evolutionary genetics analysis version 6.0. Mol Biol Evol 30:2725-2729

Thompson JD, Gibson TJ, Plewniak F, Jeanmougin F, Higgins DG (1997) The CLUSTAL_X windows interface: flexible strategies for multiple sequence alignment aided by quality analysis tools. Nucleic Acids Res 25:4876-4882

Wang JC, Ni L, Song Y, Rhodes G, Li J, Huang QW, Shen QR (2017) Dynamic response of ammonia-oxidizers to four fertilization regimes across a wheat-rice rotation system. Front Microbiol 8:630

Wang QQ, Xu H, Ma CB, Xue YD, Wang CJ, Xu MG, Zhang WJ (2018) Change of soil fertility and productivity of purple soil in western China in recent 30 years. Plant Nutr Fert Sci. 24:1492-1499. https://doi.org/10.11674/zwyf. 18188

Wang MZ, Wang SY, Long X, Zhuang LJ, Zhao X, Jia ZJ, Zhu GB (2019) High contribution of ammonia-oxidizing archaea (AOA) to ammonia oxidation related to a potential active $A O A$ species in various arable land soils. J Soil Sediment 19:1077-1087

Wessén E, Nyberg K, Jansson JK, Hallin S (2010) Responses of bacterial and archaeal ammonia oxidizers to soil organic and fertilizer amendments under long-term management. Appl Soil Ecol. 45:193-200 
Wu D, Senbayram M, Well R, Brüggemann N, Pfeiffer B, Loick N, Stempfhuber B, Dittert K, Bol R (2017) Nitrification inhibitors mitigate $\mathrm{N}_{2} \mathrm{O}$ emissions more effectively under straw-induced conditions favoring denitrification. Soil Biol Biochem 104:197-207

Xiao Y, Tang JL, Wang MK (2016) Physicochemical properties of three typical purple soils with different parent materials and land uses in Sichuan basin China. Nat Resour Eng 1:59-68

Yang HK, Wu G, Mo P, Chen SH, Xiao Y, Ma HL, Wen T, Guo X, Fan GQ (2020) The combined effects of maize straw mulch and no-tillage on grain yield and water and nitrogen use efficiency of dry-land winter wheat (Triticum aestivum L.). Soil Till Res. 197:104485

Ye XX, Ye Y, Chai RS, Li JL, Ma C, Li HY, Xiong QZ, Gao HJ (2019) The influence of a year-round tillage and residue management model on soil $\mathrm{N}$ fractions in a wheat-maize cropping system in central China. Sci Rep 9:4767

Zhalnina K, de Quadros PD, Camargo FAO, Triplett EW (2012) Drivers of archaeal ammonia-oxidizing communities in soil. Front Microbiol 3:1-9

Zhang LM, Hu HW, Shen JP, He JZ (2012) Ammonia-oxidizing archaea have more important role than ammonia-oxidizing bacteria in ammonia oxidation of strongly acidic soils. ISME J 6:1032-1045
Zhang HL, Sun HF, Zhou S, Bai NL, Zheng XQ, Li SX, Zhang JQ, Lu WG (2019) Effect of straw and straw biochar on the community structure and diversity of ammonia-oxidizing bacteria and archaea in rice-wheat rotation ecosystems. Sci Rep 9:1-11

Zhou ZF, Shi XJ, Zheng Y, Qin ZX, Guo T (2014) Abundance and community structure of ammonia-oxidizing bacteria and archaea in purple soil under long-term fertilization. Eur J Soil Biol 60:24-33

Zhou ZF, Wang MX, Liu WL, Li ZL, Luo F, Xie DT (2016) A comparative study of ammonia-oxidizing archaea and bacteria in acidic and alkaline purple soils. Ann Microbiol 66:61-623

\section{Publisher's Note}

Springer Nature remains neutral with regard to jurisdictional claims in published maps and institutional affiliations.

\section{Submit your manuscript to a SpringerOpen ${ }^{\odot}$ journal and benefit from:}

- Convenient online submission

- Rigorous peer review

- Open access: articles freely available online

- High visibility within the field

- Retaining the copyright to your article

Submit your next manuscript at $\boldsymbol{\nabla}$ springeropen.com 